\title{
Christian Faith in Dialogue with Contemporary Culture in the Personalist Thought of John Paul II and Cardinal Stefan Wyszyński
}

\author{
RYSZARD FICEK \\ Cutchogue, NY, USA \\ rficek@optonline.net; ORCID: 0000-0001-5238-6767
}

\begin{abstract}
This article presents the intellectual legacy of both John Paul II and Cardinal Stefan Wyszyński as advocates of a personalist view of culture. Their teaching emphasizes the person and human dignity in striving for human self-fulfillment in a community seeking God's transcendence. In this regard, their personalist vision of culture was defined in the context of the Second Vatican Council's teaching. Therefore, the theological anthropology of both John Paul II and Cardinal Wyszyński is based on personalism, communion, dialogue, and freedom. Nevertheless, when God is marginalized by human activity, especially by the ideology of secularism and religious indifferentism, a severe cultural crisis arises. As a result, the dialogical character of the teaching of John Paul II and Cardinal Wyszyński in the dimension of Christian culture emphasizes inculturation and evangelization of human activity. On the other hand, the Christocentric and personalist context of their concepts reflects the theocentric and anthropocentric vision of culture, which, rooted in praxeological pastoral thought, displays their views on culture not only in the dimension of philosophical and theological doctrine but above all as a pastoral vision presenting Christian culture integrated with contemporary existential experience and focused on the perspective of "a new heaven and a new earth" (cf. 2 Cor 12:4; Rev 4:2-8; 21:2-10).
\end{abstract}

Keywords: faith, personalism, culture, John Paul II, Cardinal Stefan Wyszyński, secularization, religious indifferentism, evangelization

The analysis of the phenomenon of culture demonstrates the fundamental dimension of human existence, which, by conditioning the human person's development, determines human life and activity in practically all their aspects. The unique value of Christian culture, especially on its personalist level, is expressed in striving to achieve complete personal maturity. Thus, it enables the realization of human potential and personal vocation in the temporal and supernatural aspect, despite the contamination with original sin. Based on earthly reality, Christian culture permeates all its dimensions but is ultimately oriented towards the supernatural. The dialogue of Christianity with culture, therefore, by its very nature should be expressed both in the evangelization of culture and in the inculturation of the Gospel, carried out in profoundly differentiated socio-political conditions.

The mutual relations between the human person and culture are eloquently defined by the words of John Paul II in UNESCO: "Culture is the proper way of human 
existence and reality. Man is the only subject of culture in the temporal world, and he is also his only object and goal. Culture is what makes man more of a human being." Therefore, it is not enough to look for the truth about man in his culture, although it is an important area of his knowledge and understanding. You have to start with a question about the essence of man, his humanity. If culture is an expression of human beings' work on their own humanity, the fundamental question to be answered is: who is a man, and who is he supposed to be? What is there to improve? What is the essence of humanity? These questions boil down to one thing: what is the truth about man? Can it be known without seeking the truth about the world, about God, man's relationship to himself, other people, and God?

According to Christian personalist principles, the center of culture is God-Man: Christ understood as Truth, Life, Love, and the Way. He teaches the integral view of man. "Without Christ, man cannot fully understand himself. He cannot understand who he is, what his proper dignity is, or his calling and final destiny." The personalist perspective of Christian culture, placing the person at the center of considerations as the fundamental subject and source, gives him a personal, social, and dynamic character. That is why culture is not a static and "closed reality" but is continuously transformed. As an expression of human activity, the phenomenon of culture contains all the richness of the human personality. Presenting Christian culture from the perspective of the mystery of Creation and Redemption demonstrates man's creative activity in a history-saving dimension. Thanks to this, Christian culture becomes included in the supernatural culture, the foundation of Jesus Christ. Through the Incarnation, He enters man's history, connects him with God, and creates a culture in which the divine realm is re-connected with the human world. ${ }^{3}$

Jan Paweł II, “W imię przyszłości kultury,” 197-198.

2 Wyszyński, "Chrystusa nie można wyłączyć z dziejów człowieka," 241. Primate Wyszyński’s anthropology presents a human person in relation to two salvific-historical events, i.e., the mystery of God's creation and the redemption events of Jesus Christ. However, human life's environment is an actual earthly reality, where a human person lives and works, develops, as well as improves himself. In other words, a man matures and grows personally in a specific place and time. It is the environment of human life, culture, and salvation (cf. Wyszyński, "List pasterski O chrześcijańskim wyzwoleniu człowieka," 30-46). John Paul II similarly interpreted culture. In Prague, to people of science and culture, the Holy Father said: "Without a transcendent perspective, without the sense of transcending visible reality, every culture remains a pathetic fragment, like the Tower of Babel. You cannot build culture by ignoring or stubbornly rejecting what cultus is - respect, respect. An uncultured person and an uncultured nation is a person and a nation without respect for themselves, for their neighbors, for the world, for God" (Jan Paweł II, "Przemówienie do ludzi nauki i kultury," 334).

3 In this sense, contemporary culture urgently needs a proper, "healthy" anthropology that recognizes and emphasizes the primacy of the person: a being in which the physical, mental and spiritual dimensions are integrated. Culture is what makes man as a person more human: more "is." It is also the basis of this paramount distinction between what man is and what he has. Everything that a man "has" is essential for culture; it is culture-forming, insofar as man, he can at the same time "be" more fully as a human being, more fully become a human being in all dimensions of his existence proper to humanity. Cf. Jan Paweł II, "Przemówienie na Uniwersytecie," 310. 
Primate Wyszyński's statement should be understood in a similar context, as he states: "The level of unifying culture is higher than that of separating culture. All paths of this culture lead through human nature, the nation, the state, and the church community.4 "Everything came out of the unity of God, everything was created through one paternal love, and with the help of this love, and everything is to return to this unity." The humanizing function of culture, understood as the development of man in all his qualities, can be confirmed, however, as long as the culture is guaranteed an integral concept of man - a spiritual and material being, temporal, but oriented towards eternity, living in the time and called beyond all time, rational and, therefore, free - whose freedom is rooted in reason and free will.

\section{Faith and Culture: A Mutual Correlation}

A personalist vision of culture is a fundamental teaching dimension for Cardinal Stefan Wyszyński and John Paul II. Central to it is the community dimension of culture, which is essential concerning the family, the church, as well as local communities, and the nation. Undoubtedly, the Christian culture helped to survive the most difficult moments in Poland's history, especially during partitions and post-war enslavement by the totalitarian system of Marxist-Leninist ideology.

It was Christian culture that had become a kind of "enclave of freedom" and space for commentary as well as reflection on reality in its old and contemporary manifestations. In this sense, Christian culture has created a strong sense of separateness and strength, and at the same time, creatively inspired the individual to commit to the transformation of temporal reality in the perspective of "a new heaven and a new earth" (cf. Matt 5:10 and 19:28-30; Luke 10:21 and 14:14; Rev 4:2-8; 21:2-10). After all, it was in the space of Christian culture that the entire society's life took place during the last two centuries when it was often the only possible forum for expression for many Poles generations. Therefore, if we recognize that history is driven by culture, we will quickly understand that this is the approach to history that shaped Karol Wojtyła, the future Pope John Paul II, and the Primate of the Millennium, Cardinal Stefan Wyszyński.

Their pastoral ministry grew out of Polish culture's entire ethos and its context of faith, rooted in the Christian tradition. It is especially evident in how both hierarchs tried to place culture at the center of the Church's pastoral efforts in the "New Evangelization." Indeed, the historical context from which they grew up strengthened their

Wyszyński, "Nie oczekujemy życia łatwego," 10; cf. Jan Pawet II, Pamięć i tożsamość, 64-78.

Wyszyński, "Nie oczekujemy życia łatwego," 9. 
conviction that culture is fundamental to human life. Their pastoral ministry had become an attempt to universalize the Polish experience of the community-forming role of culture, which took the form of papal reflection in official documents of the Church, post-war teaching of the Polish Episcopate, as well as in the dimension of institutional support, e.g., in the form of the "Pontifical Council for Culture."

It implements the missionary goals defined by the Holy See: (1) It undertakes initiatives to bring together evangelization and contemporary culture (marked by unbelief and religious indifferentism). These activities aim to foster "an ever greater opening [of culture] to the Christian faith, which co-creates culture and science and is a source of inspiration for literature and art." (John Paul II Inde a Pontificatus, No. 1); (2) it displays the pastoral concern of the Church to overcome the gap between the Gospel and cultures. The aim of appropriate actions in this regard is to develop practical pastoral tools for the evangelization of cultures and the inculturation of the Gospel (cf. ibid., no. 2); (3) It supports the relationship of the Church (including local Bishops' Conferences) and the Holy See with the world of culture (cf. ibid., no. 3 ); (4) He engages in dialogue with non-believers who are open to such relations with the Church and ready to cooperate with her (cf. ibid., No. 4); (5) Maintains and coordinates the work of the relevant Pontifical Academies (ibid.); (6) Participates in the implementation of cultural initiatives of other dicasteries of the Holy See; (7) Maintains constant dialogue with local Churches and religious superiors in order to foster the active presence of the Church in local cultural life; (8) Cooperates with universities and international Catholic, historical, philosophical, scientific, artistic and intellectual organizations in order to multiply joint initiatives; (9) Participates in initiatives of international organizations (such as the United Nations Educational, Scientific and Cultural Organization or the Council of Europe) devoted to culture, philosophy of science, and anthropology. The aim of these activities is the visible participation of the Holy See in international congresses in the field of science, culture, and education; (10) Monitors the development of national policies and activities in the area of culture; (11) Facilitates the dialogue between the Church and culture through universities and research centers, primarily Catholic cultural centers, organizations associating artists, specialists, and researchers, and initiates significant activities for the integration of the world of culture; (12) He invites people who have a considerable influence on contemporary culture to come to Rome so that they can learn more about the Church's experience in this field and at the same time enrich the knowledge of the Holy See. These initiatives make the Council a place for meetings and dialogue.

6 Out of concern for the consistent and competent implementation of the cultural intuitions and guidelines of the Council towards culture, John Paul II, with a letter dated May 20, 1982, addressed to the Secretary of State, established the "Pontifical Council for Culture" (cf. Jan Paweł II, "Powołanie do życia Papieskiej Rady do spraw Kultury," 765-768). 
In this context, culture becomes the foundation of the New Evangelization. In the opinion of both representatives of the Church, faith and culture are in a mutual relationship where they must remain inextricably linked if they are to develop one another. In this sense, culture is the vehicle of dialogue between believers and non-believers. ${ }^{7}$ In turn, art is an important area for cultural dialogue. It is here that both language, gesture, and ideas are intertwined as thoroughly as possible, often in a universal structure. In other words, in the personalist sense, culture should be built on the common foundation of the civilization of love to be authentically human. It is accomplished only through faith and grace that flow from the mystery of the Redemption accomplished in Jesus Christ.

Therefore, for both the Pope and Cardinal Wyszyński, the subject of culture is the man who grows through it. Culture itself is constituted by human praxis to such an extent that it makes "people more human." Thus, the most profound aspect of culture is the possibility of human activity, satisfying the human need for creative expression in the world (the humanizing role of culture). A complete understanding of the "humanizing" role of culture requires the presentation of the above concept in a broader context of contemporary personalistic thought, of which Karol Wojtyła, the later Pope John Paul II, was a particular representative. Especially the personalistic interpretation emphasizes that the source of the act is a man. In this context, the human act has two dimensions: internal and external. The "internal act" is in a particular way related to consciousness. Engaging the "external" aspect of the human act is not a simple consequence of human corporeality but a conscious entry into external reality. The experience of a human act must be comprehended as a whole. The experience of a human act, however, contains two basic structures: man's act and "something that happens in him." As a result, one should notice human activity and passivity - correlation and opposition. However, the mentioned opposition is not a contradiction, but it shows the dynamic situation of the subject passing from potentia to actus. Thus, a person experiencing an act undergoes an internal change as a person - something happens to him - but at the same time, in this situation of "going on," he becomes involved as a subject in external reality, that is, he acts. Subjectivity and agency in man are closely related. Therefore, it is not enough to say that this act is human and that this act is a human act because axiology alone is not enough to explain the subject's dynamic involvement.

There is a need to link axiology with ontology. The tension between potency and act - and at the same time binding these two poles - causes a new way of existence of the human person, and thus also a new way of acting - engaging. Therefore, as

7 The "Secretariat for Unbelievers" was established on April 9, 1965, by Pope Paul VI. Its purpose was to study atheism and its causes. Moreover, he dealt with establishing a dialogue with non-believers. In May 1993, Pope John Paul II joined him with the "Pontifical Council for Culture." Cf. John Paul II, Inde a Pontificatus. 
the author himself defines, there is a live relationship between the person and the act, thanks to which a person acts responsibly. In the structure of a human act, its transcendence and immanence should be emphasized. It means that a person is aware of his action and, at the same time, experiences this action. It is an action based not only on an emotional, rational and free nature but also on the acting person. So, agere is a result of esse. The dynamic human position understood in such a way consequences in the unity of the person with the act, the integration of many relations that cause a specific action to be defined as human. And although the Church is not the culture in herself, it exists in the space of culture. Culture, even though it is influenced by it, also affects the Church in the inculturation dimension. ${ }^{8}$

Therefore, a personalist vision of culture cannot be understood without this basic paradigm: faith is not meant to be private and individual but must create culture; that is, it must bear witness. The synthesis between culture and faith is a requirement not only of culture but above all of faith. Faith that does not become culture is not entirely accepted, not thoroughly thought out, not lived faithfully. If the Church does not attempt to speak the language of culture, she will withdraw from molding it and influencing it - which means that she will retract from the evangelization. The matter is not trivial from the perspective of faith, and therefore from the standpoint of the fundamental mission of the Church: "Woe to me if I do not preach the Gospel!" (cf. 1 Cor 9:16). So it is not enough to proclaim the message of truth in the context of the "Good News." It becomes necessary to take appropriate actions to incorporate this message into the contemporary world's particular reality. Therefore, the Incarnation dogma becomes the key to comprehending the personalist vision of Christian culture: thus adapting the announcement of the Gospel to the conditions of contingency, history, societies, and state communities.

The fundamental object of the Church's endeavors is evangelizing a culture that accepts the integral truth about man, demonstrates the dignity and greatness of his vocation, and merges Christian anthropology into its value system. In the personalist perspective, the "leading creator" and direct entity of culture is a human being understood as an individual human person. ${ }^{9}$ Thus, culture is a reality derived from man, resulting from his personal action and expressed through his personal experiences, both individual and social. By creating culture, impressing his spirituality's

\footnotetext{
Cf. Wojtyła, Osoba i czyn, 48-79.

"The creator of culture, the Cardinal emphasizes in his teaching, is first and foremost a human person. Although communities such as the state or nation can create more favorable conditions for its development, the ultimate creator, maker, and inspiration is the man himself" (Wyszyński, "Konstytucja Pastoralna," 119-120). In his teaching, Cardinal Wyszyński emphasizes two essential aspects of human involvement in culture. On the one hand, the man shapes the culture in which he reflects his inner world; on the other, he develops and forms this interiority through culture. The integral connection of these two elements of culture means that although they constitute a wholeness, they interpenetrate, co-create and condition each other. Cf. Celej, Kultura chrześcijańska dusza narodu, 31.
} 
mark on his life and works, on relationships with God, people and nature, he gives it an idea, theme, and motive.

Thus, by creating culture, a human person also forms himself, developing himself as a spiritual and physical being. ${ }^{10}$ In other words, man embraces everything that he has consciously and intentionally shaped: progress, science, art, technology, co-thinking, and cooperation with people. This whole reality transformed in and beyond him becomes the object, content, and goal of culture."11 The above perspective is rooted in the very nature of a man who "[...] seeks to maintain his existence. [...] We know it in the most ontological and eschatological terms - as maintaining one's personality not only in the economic sense but also in the sense of his development and securing his duration - his eternal time." ${ }^{12}$

However, one cannot speak of the human person's fullness without considering his transcendent dimension. The specificity of religious values lies in the fact that they connect the human person with a reality separate from both the whole world of things and people - with the transcendent realm - pointing to the vertical dimension of human existence, from the point of view of which other aspects dimensions acquire a new meaning, intensity, and deepness. From a personalist perspective, this means that a proper understanding of the phenomenon of culture is possible only thanks to God, "[...] who shaped human nature in such a way that one of its most perfect life tasks is for man to become a complete human being, so that [...] within myself a physical and spiritual personality." ${ }^{13}$ The creation of man in the image and likeness of God, as well as calling him to cooperate with God's economy of the world, means that the entire reality of culture - the direct creator of which is a man - only in God the Creator finds its original source as well as absolute subjectivity and explanation. ${ }^{14}$ However, man as a person, a kind of micro-world and micro-community, becomes the main goal and content of culture. Human involvement, guided by reason and will, is by nature purposeful. Thus, culture, which on the one hand is aimed at building a better world and the fullness of the human person, on the other hand, becomes the image of a perfected human being. "The creativity of each person testi-

10 According to Wyszyński ("Zadania i środki oddziaływania Kościoła," 59-60), a man whose precedence is announced by the Creator, who made him the king of creation and subordinates everything to him, has tasks in this world in temporal and eternal order. In the temporal order, the development of the personality with the help of the development of the material culture of the globe; in the eternal order, the deification of the personality so that man does not set himself deterministic limits, but knows that in personal development he is to reach his Creator.

11 Cf. Wyszyński, "O nowym człowieku w Jezusie Chrystusie," 351.

12 Wyszyński, "Homo Dei," 575.

13 Wyszyński, "Do uczestniczek zjazdu pielęgniarek," 339.

14 Cf. Wyszyński, "W słodkim jarzmie miłości," 382-383; Celej, Kultura chrześcijańska duszą narodu, 32. 
fies to him, reveals his interior, his spirit, what he lives, what is his logos and ethos, what powers he has at his disposal."15

This understanding of the complex reality of culture flows from the teaching of the Second Vatican Council. ${ }^{16}$ In this context, the good of the human person verifies the greatness and importance of culture. Thus, authentic culture holds humanistic values above all, and it is human creativity undertaken with the human being in mind and directed towards his fullness. Thanks to culture, then, the human person enters into various relationships with people and the world. "The Church, although it shows us heaven, is realistic, and although it puts the person above things [...], it is nevertheless based on earthly reality." ${ }^{17}$ Through involvement in cultural activities, a person expresses his relationship to the world. At the same time, it is a particular realization of God's calling to subdue the land. The specificity of this vocation is that man receives the privilege of participating in God's work of creating the world of culture.

\section{Culture and Its Personalist Origins, Values and Principles}

In terms of John Paul II and Cardinal Stefan Wyszyński, personalism is expressed in certain axioms, iron rules for organizing and evaluating reality. They are the superiority of spirit over matter, ${ }^{18}$ the priority of being over having, ${ }^{19}$ and the preeminence

15 Wyszyński, Zaszczytna służba Słowu, 269. In this context, the word "creativity" used by Primate Wyszyński emphasizes the dynamic nature of human involvement in culture. Truth, goodness, and beauty are not only expressed by man but also discovered, shaped, and multiplied. Cf. Celej, Kultura chrześcijańska dusza narodu, 34 .

16 The Second Vatican Council in Gaudium et Spes defines "[...] as culture in a general sense everything that man perfects and develops the multiple faculties of his spirit and body; tries to subject the world itself to its knowledge through knowledge and work; makes social life more human, both in the family and in the entire state community through the progress of morals and institutions; finally, in his works over the centuries, he expresses, transmits and maintains great spiritual experiences and aspirations so that they serve the progress of many, and even the whole of humanity" (Gaudium et Spes, no. 53).

17 Wyszyński, "Kształtowanie kultury społeczno-katolickiej w Polsce," 437.

18 Cf. John Paul II, Redemptor hominis, no. 16. The personalistic concept of the human person, exposing the greatness of man, at the same time emphasizes the infinite dignity of his person. Therefore, a man is a child of God - this is homo Dei in an ontic, moral and praxeological sense (cf. Wyszyński, "O chrześcijańskim wyzwoleniu człowieka," 19). As a human person, it is a kind of micro-world, micro-community. It is a world co-created by God together with society, fulfilled in history, redeemed by Christ, complemented by the work of the spirit and hands, and fulfilling the kairos of God's economy. Cf. Wyszyński, "Jasnogórskie zobowiązania..., 303-304; Wyszyński, “Ojcze nasz," 29; Wyszyński, "Kościół wspólnototwórczy," 149; Wyszyński, "Krzyż na szlaku Warszawy," 16-20.

19 Cf. John Paul II, Evangelium vitae, no. 98; John Paul II, Christifideles laici, no. 37. From the perspective of Christian personalism, in God, the Creator, all the desires and needs of the human person have their source. As Cardinal Wyszyński emphasized: "Man's desires and aspirations coincide with the properties of the Creator. So we have the inheritance of the Heavenly Father that Christ makes us aware of. We can safe- 
of a person over a thing. ${ }^{20}$ In this context, the personalist vision of socio-cultural life places man at the center of its analysis. In this sense, a person "is a rational and free being, is the master of creation." ${ }^{21}$ The human person's unique dignity comes from being "the only creature on earth that God willed for himself." 22

Thus, a person means a unique and particular fullness of being, ${ }^{23}$ "center and summit of all that exists on earth." ${ }^{24} \mathrm{He}$ is an independent being: ipsum esse subsistens, and this subsistence means his own existence: one in itself, from itself, and for itself. Moreover, man is a spiritual and bodily being, characterized by an integral unity. He has his own internal causality: the whole acts on parts, unlike things whose causality is external, where one element affects the other. ${ }^{25}$ The human person is

ly say that we carry within us the qualities of our Creator, our Father, and our aspirations are implanted in us in the great and powerful Womb of Heavenly Father, from which we all come. From Him, we inherit all desires, aspirations, and "pangs of hunger," which are also our life desire" (Wyszyński, "Homo Dei," 576).

20 Cf. John Paul II, Laborem exercens, no. 12, 13; John Paul II, Redemptor hominis, no. 16; John Paul II, Evangelium vitae, no. 34, 98; Jan Paweł II, List do rodzin, 13. From the latter principle, following the so-called "second imperative" of Immanuel Kant, Wojtyła derives and formulates the so-called "personalistic norm": "A person is such a being that his proper reference is love. We are just with a person if we love him - both God and people. Love of a person excludes treating him as an object of use" (Wojtyła, Miłość i odpowiedzialność, 29-30).

21 Wyszyński, "Społeczność przyrodzona i nadprzyrodzona," 61.

22 John Paul II, Veritatis splendor, no. 13. "Apart from a man - emphasizes Cardinal Wyszyński - there is no personality, no rationality, no freedom" (Wyszyński, "Społeczność przyrodzona i nadprzyrodzona," 61). Karol Wojtyła, analyzing the subjectivity of the human person, emphasizes that in the philosophical tradition that arose from the definition of homo-animal rationale, a man was above all an object, one of the objects of the world to which he visibly and physically belongs. Objectivity understood in this way was connected with the general assumption of human reducibility. Subjectivity is, as it were, a triggering term for the fact that man does not allow himself to be reduced in his essence and to be "completely explained" by the nearest gender and species difference. Thus, subjectivity is, in a way, a synonym for what is irreducible in man. Cf. Wojtyła, Podmiotowość $i$ «to co nie redukowalne», 23.

23 Cf. Wojtyła, Miłość i odpowiedzialność, 22. A specific way of being, characteristic only for a man, determines his functioning in the socio-cultural reality and verifies his proper position in the entire ontic structure. Although, according to the Primate, "[...] man in his actions and efforts to master the earth is limited [...] nevertheless should remember that he has precedence over the created world" (Wyszyński, "Najważniejszą wartością na świecie jest człowiek," 961-962).

24 John Paul II, Christifideles laici, no. 37. Although John Paul II, like Cardinal Stefan Wyszyński, does not give a full definition of a person anywhere, one can formulate such a description based on their teaching. A person is someone who is self-existent in the objective and subjective sense, spiritually-material, rational, free, realized, but still realizing himself both in himself and the community of others, complementing himself especially in action as well as agency, and finally fulfilling himself in communion with Uncreated Person. Cf. Bartnik, "Osoba i Kościół," 89.

25 John Paul II, Familiaris consortio, no. 11. "The spiritual-corporeal nature of a human being, expressed in his free and rational action, is a constitutive quality of man" (cf. Wyszyński, Uświęcenie pracy zawodowej, 200). Therefore, the human person is a particular separate being, permanent, integrated despite the complexity, and at the same time unifying and integrating numerous activities and features as their subject, substrate and cause. The spiritual element in man fulfills the role of a visible sign of God's closeness to the material world. Through the body, a human person connects with the surrounding world, he is a part of it, he lives and acts in it, is subject to its laws, but also occupies a unique position in it. He is its master: he organizes it, controls it, transforms it and uses it for his life and development. The body - as a material 
purposeful; the item is mechanical; the person himself determines his goal and constitutes value for himself (the so-called internal teleology, i.e., its orientation towards the good of the person ${ }^{26}$ ).

On the other hand, a thing has a purposefulness determined from the outside, and as such, is something indifferent to itself. The person cannot be replaced entirely, and there is no price for him. As an independent subject of a rational nature, he becomes the perfect being in all nature. Thus, the human person becomes the first and fundamental value of the entire social order. ${ }^{27}$ As a result, the essential "[...] creator of culture is a human person"28: the main subject of history, the highest value, and the most spiritual reality of this world. As an important subject, expressing himself through the immaterial and immortal soul, he realizes himself through conscious and free action, which actualizes the possibilities contained in his nature. ${ }^{29}$

This fact explains such spiritual activities as cognition, love, and freedom. The complex structure of personality makes a man an ontically multi-layered being. As a rational and free being, he becomes at the same time an active entity that evaluates and creates values. Thus, the very existence of a human person and the purpose as well as the meaning of his life in the level of this world cannot be explained and must be shown in its whole personal dimension. Therefore, only a personalist vision of man - emphasizing both his central position in the entire created world, as well as the entire perspective of his natural and supernatural vocation - makes it possible to discover who the human person is to understand his value and meaning. ${ }^{30}$

element - is also a kind of bridge connecting the reality of the material world with God. Cf. Kowalczyk, Człowiek a społeczność, 108-115.

26 Cf. John Paul II, Veritatis splendor, no. 78. Although inscribed in earthly reality becomes a part of it, the spiritual-bodily structure, personal dignity, and supernatural calling make him appear as a being that surpasses the entire created world. However, it turns out to be a place where the human person - as the main subject of all creative activity - can realize his personality and achieve the right and satisfactory goal. (cf. Wyszyński, "Społeczność przyrodzona i nadprzyrodzona," 61). Man created in the womb of the world is the subject of the world, history; he is moving towards infinity. Moreover, he is the king of creation, but also his servant. He is left not only in the dilemma of truth-error, freedom-alienation, happiness-unhappiness, but most of all, moral good and evil. Morality turns out to be a new dimension of being, and it determines man: it constitutes him, makes him, verifies, and fulfills him. In morality, a man "happens" as a person. Cf. Bartnik, Teologia kultury, 91.

27 Cf. Wyszyński, “Najważniejszą wartością na świecie jest człowiek,” 961-962.

28 Wyszyński, "Konstytucja Pastoralna," 118.

29 Action in the Aristotelian-Thomistic philosophy, to which the personalism of Wyszyński and John Paul II alludes, is understood as the highest act of substantial being. It is an expression of human possibilities contained in his substantial nature. Considering dialectical-processual philosophy referring to Heraclitus and Hegel - its heir is also Marxist dialectical materialism - the priority of action over being is recognized. Based on this trend, it is logical to say that it was the culture that created man. However, the ontic order is the opposite: it is a man who makes the culture through which he develops and perfects. Cf. Kowalczyk, Filozofia kultury, 90.

Cf. Wyszyński, "Chrystusa nie można wyłączyć z dziejów człowieka," 297-302. 
In personalist cultural anthropology, a man appears as an eternally intended being, rooted in God's mind and embodied in a specific historical reality. ${ }^{31}$ His total value, however, is expressed in the perspective of two fundamental salvific events: the creation of man in the image and likeness of God and the saving-redemptive event of Jesus Christ. Thus, "[...] all creation and redemption are the next stages of the incarnation of God's thought, which has existed in each of us from the beginning." ${ }^{32}$ These two most critical salvific-history dimensions - the creative ${ }^{33}$ and the saving-redemptive ${ }^{34}$ - reveal not only the extraordinary dignity of the human person but also his primacy in the entire created world.

\section{Secularism, Religious Indifferentism, and the (Post-) Modern Culture}

The proclamation of Christ and his Gospel is a duty of the Church of all times and is directed to every person. The forms of fulfilling this duty depend primarily on people's needs and circumstances in a given time and cultural context. However, even a cursory attempt to examine the signa temporum of contemporary culture and civilization indicates that it is imbued with secularization and religious-moral in-

31 In his speech, Primate Wyszyński states: We are eternal in God's thought [...]. We have been for centuries in the mind of the Heavenly Father next to the reality of the existing Eternal Logos (Wyszyński, "W słodkim jarzmie miłości," 5-6).

32 Wyszyński, "W słodkim jarzmie miłości," 5-6.

33 God is more and more fully involved in the act of creating man. The direct encounter of the Creator with the created man produces an intimate personal dialogue expressed in a creative unity based on the Love of God Himself. "Let us make a man ..." - emphasizes Cardinal Wyszyński - that is, let us pass on the part of Our Love. Let us hand over a being created in our image and likeness, who would be able to accept our Love, participate in it and pay with love for the received Love " (Wyszyński, Jesteśmy z mitości i dla mitości, 10). The dignity of the human being is expressed as man's extraordinary closeness to God with regard to the way of creation and the content of the created man. For man is not created in the image and likeness of matter, but in the image and likeness of God. He bears the likeness of God in him because he is like God, who has made the whole world subordinate to himself and rules over it. Man has been received at his disposal the world created to be its ruler, but this does not exhaust the whole idea of the image and likeness. Made in the image and likeness of God, he is able to know and love his Creator (cf. Wyszyński, "O katolickiej woli życia," 33).

34 The natural dignity of the human person culminates in the person of the God-Man "Jesus Christ. Without Christ, Cardinal Wyszyński emphasizes, man cannot fully understand himself. He cannot understand who he is, what his proper dignity is, or his calling and final destiny" (Wyszyński, "Chrystusa nie można wyłączyć z dziejów człowieka," 241). In the mystery of God incarnate, we find an explanation of the mystery of man and his dignity. Christ is "[...] a new proof of God's love for man, the culmination of which we see in the work of redemption. In Jesus Christ, the creative-saving love of God is concentrated and historicized. The person of the Son of God [...] combines the divine and human nature, the life of grace and nature, the supernatural and the natural, heaven and earth" (Wyszyński, "O chrześcijańskim wyzwoleniu człowieka," 21-23). 
difference. This fact is repeatedly emphasized by John Paul II, pointing to "the loss of memory and Christian heritage, accompanied by a kind of practical agnosticism and religious indifference, causing many Europeans the impression that they live without a spiritual backing, like heirs who have squandered the heritage left to them by history."35

Opposing such thinking and attitudes of this kind requires knowing and interpreting them. The phenomena mentioned in the article's title - secularism, religious indifferentism, and the crisis of contemporary culture - have much in common in their content and complement each other. In this context, secularization emerges as a principle, fact, and ideology. ${ }^{36}$ The above concept tries to emphasize man's cognitive power, which leads to the omission of God or His denial. It is also the cause and form of relegating religion and God to the "interior" of social and public life and developing religious and moral individualism. Consequently, it manifests itself in the atheization of science and culture, progressive socialization and monopolization of socio-cultural life (mass-culture promoting an attitude "do what you want"), resignation from external manifestations of religiosity, rejection of the relationship between religion and local culture, or national practices and a departure from traditional religious practices and moral attitudes. ${ }^{37}$

However, religious indifferentism is understood as a religious and moral lack of interest and concern, which is much more dangerous for contemporary Christian culture. Such an attitude towards God and religion is dangerous both in its nature and scope. In this sense, it is the most grievous form of atheism. It questions not only the possibility of God being able to exist but also the meaning of the existence of religion and the sense of religious needs rooted in human nature. Moreover, religious indifferentism as an attitude is utterly inaccessible to religious dialogue because it negates its need. ${ }^{38}$ Also, the dimensions of this attitude are becoming more and more

35 Jan Paweł II, Ecclesia in Europa, no. 7. Already in 1991, saying goodbye to his compatriots in Warsaw, John Paul II said: "We live as if God did not exist, it is also part of the European spirit. Part of the modern European tradition. Christ [...] was put in brackets, and a different European mentality began to emerge; mentality, which can be briefly expressed in the sentence: We think like this, we live as if God did not exist" (Jan Paweł II, Czwarta Pielgrzymka do Polski, 223).

36 (1) In the first sense, secularization is the thesis that science, technology, and culture in their development should be guided by "autonomy" without any connection with religion and theology (broadly understood autonomy of earthly reality). (2) As a fact, secularism manifests itself in eliminating the sacred factor from the public life of individuals and human communities. (3) In the sense of ideology, secularization identifies itself with secularism. In this sense, the world's entire reality is explained by itself, without the need to resort to a God who becomes redundant or even disturbing. Cf. Jan Paweł II, Evangelii nuntiandi, no. 55.

37 Cf. Kerber, "Führungsethik in einer säkularisierten Industriegesellschaft," 651-661; Lübbe, Der Lebenssinn der Industriegesellschaft, 16-54.

38 On the socio-cultural level, religious and moral indifferentism manifests itself in several specific categories. Those are:

- the so-called "Cultural violence" expressed in all kinds of brutality, violence, terrorism, and "boorishness";

- "accelerating the rhythm of life," as well as "indifference of action and passion" inscribed in the expressly understood consumerism and practical materialism adopting the axiological principle of time is money; 
dangerous. Religious and moral indifferentism is associated with certain features of contemporary culture and civilization, fitting into the specificity of the so-called "(Post) modern consciousness." In this sense, it ceases to be merely a personal matter of the contemporary intellectual elites who create the reality of culture and become a global historical phenomenon. ${ }^{39}$ On the ideological and moral level, religious indifferentism manifests itself in the inability to face truth and goodness issues, as well as to meet the obligation to maintain consistency between life and ethical requirements. It is also connected with the loss of the sense of the transcendent meaning of human existence and loss in the field of ethics, even including such fundamental values as respect for life and family. ${ }^{40}$

Concerning truth and goodness, indifferentism is subject to all the modern tendencies of relativism and skepticism that have led to the total undermining of the truth. In this sense, relativism places its position between the negation of truth and the omission of the possibility of seeking it. The man of the past put God at the center of reality, the source of truth and goodness. Contemporary man makes himself or a community the measure of truth and goodness. However, it is not an absolute and unchangeable measure. An indifferentism, anchored in anthropocentrism of (post) modern "fluid reality" concerning the category of good, is characterized by historicism and immanentism. In this case, man as the subject of morality is indifferent to all transcendence. It manifests that (post) modern man becomes a sci-

\footnotetext{
- "the need to be trendy" consisting in the absolute necessity to adapt to fashion, style, and the current rhythm of life, which is embodied by idols created by the mass media;

- "compulsion to success" achieved at any cost, and often "at a low price," where religious and moral values are often the subject of mockery and baiting;

- "modern doubt", when problems of a religious and moral nature are treated as apparent, and everything can be solved and explained using the theory of "logical positivism";

- "inability to dialogue" expressed by excluding religious and moral values and problems from the dialogue;

- "indifference of tolerance," which is understood as the equality of all ideas, religions, norms, and human behavior, where the categories of good and evil depend on individual opinions and decisions, and values and anti-values are placed on the same axiological plane. Cf. Wyszyński, "Ojczyznę wolną zachowaj nam Panie!”, 367-369; Wyszyński, "Ale nie depczcie przeszłości ołtarzy..., 378-380; Wyszyński, “Tajemnica więzi z ojczyzną," 483-487; Swastek, "Laicyzacja życia publicznego," 23-32; Poupard, "Non-croyance et cultures d'aujourd'hui," 3-21; Legutko, "O tolerancji," 113-132; Pottmeyer, "Die Zeichen der Zeit," 166-176.

39 Cf. Mariański, Religia i Kościót, 83-84.

40 As John Paul II put it: "How can we remain silent, for example, about the religious indifference which causes many people today to live as if God did not exist, or to be content with a vague religiosity, incapable of coming to grips with the question of truth and the requirement of consistency? To this must also be added the widespread loss of the transcendent sense of human life, and confusion in the ethical sphere, even about the fundamental values of respect for life and the family. The sons and daughters of the Church too need to examine themselves in this regard. To what extent have they been shaped by the climate of secularism and ethical relativism? And what responsibility do they bear, in view of the increasing lack of religion, for not having shown the true face of God, by having "failed in their religious, moral, or social life"? (John Paul II, Tertio Millennio Adveniente, no. 36).
} 
entist, materialist, permissive, and finally a morality creator. ${ }^{41}$ And that means axiological indifferentism. Such an outlook option causes a change in the very essence of the good, that is, its "internal" measure. Indifferentism treats "relative good" as an absolute and ultimate good. We are then dealing with a shortened perspective of good, to the point of blurring the line between good and evil. It also underlines the norm-forming concept of conscience. "Creative conscience" is no longer the giftedness of a person, thanks to which a person discovers a law which he does not impose on himself, but an arbitrary judgment about the good and moral evil of human acts (a man as a judge of morality who determines what is good and what is wrong).

The ways of thinking and existential attitudes mentioned here display the primary forms of manifesting religious and moral indifferentism in man's contemporary socio-cultural reality. Consequently, the sphere of the profane frees itself from ties with the sphere of the sacrum. Religion no longer determines neither everyday life nor the broadly understood cultural sphere of man, which are now subject to the "logic" of secular values. Besides, secularization spontaneously leads to the weakening of religious and ecclesiastical ties, as well as creates indifferentism towards all kinds of "transcendence," up to strictly atheistic standpoints. In this context, the adverse moral and educational effects of secularization and indifferentism directly affect the entire culture's impoverishment, introducing axiological nihilism into earthly human existence. It is disastrous because the omission of transcendence, objective truth, and goodness puts man on an existential strand and exposes him to destructive frustration and axiological emptiness.

The above observation already displays the normative nature of secularism and religious and moral indifference in the context of contemporary culture crisis. The realization of this duty becomes even more visible in the cultural reality when we learn more about this phenomenon's effects. They are particularly visible concerning the three fundamental values of Christian culture: truth, goodness, and sacrum. The attitude of indifferentism to the category of truth manifests itself in negating its

41 Such thinking manifests itself in several characteristic attitudes:

- aversion and resistance to the promises of faith that appear "bland" and "illusory" because they do not guarantee any "concrete" happiness in the future and do not solve the fundamental problems of earthly life immediately, such as suffering, poverty, etc.;

- "scientific indifference" putting absolute trust in science and technology, which as a rule should not be concerned with God, religion, and morality. Hence, the above issues should be considered irrational;

- "experience of emptiness and loneliness," presented by many young people who live "at ease" in the belief that human existence is characterized by the "unbearable lightness of being";

- "indifference to destruction," consisting in a complete lack of interest in life "here and now," treating the world as "total nonsense." Often, however, anarchist attitudes are endorsed;

- "breaking interpersonal ties," as they are considered senseless and, as a consequence, lead to a loss of empathy and anti-social attitudes;

- "youth indifference" are attitudes such as: "do whatever you want," "I don't care about anything yet," etc. Cf. Mariański, Młodzież między tradycja i ponowoczesnością, 205-240; Nash, "Genealogies of Indifference?," 25-42; Catto, "Interfaith Dialogue," 65-82. 
existence and even the need to discover it. This type of mentality most often takes the form of cognitive agnosticism and the detachment of truth from human existence, and consequently, knowledge from man's action. ${ }^{42}$ As Pope John Paul II emphasized: "The great certainties of the faith are being undermined in many people by a vague religiosity lacking real commitment; various forms of agnosticism and practical atheism are spreading and serve to widen the division between faith and life; some people have been affected by the spirit of an immanentist humanism, which has weakened the faith and often, tragically, led to its complete abandonment." ${ }^{43}$

Concerning the category of "good," the secularization of the cultural space, religious indifferentism manifests itself in moral immanentism and relativism, a false understanding and experiencing the phenomena of freedom, as well as a wrong evaluation of moral good and evil. Therefore, "one encounters a sort of secularist interpretation of Christian faith which is corrosive and accompanied by a deep crisis of conscience and Christian moral practice." ${ }^{44}$ However, the beginning of cultural growth and the development of authentic interpersonal relationships that determine the proper development of culture is good, rooted in the love of God himself. "If God is love, and a man His child, [...] then man is also out of love, and love belongs to man's nature, that only thresholds and closed doors are the powers of truth, freedom, and justice - where there is no love." 45

Considering the sacrum, religiously idiosyncratic people usually present agnosticism or the so-called "general faith." People indifferent to matters of faith may sometimes recognize the existence of the so-called "Higher Power" in a purely speculative manner. Nevertheless, the above belief does not affect their specific personal life. John Paul II characterizes the above situation as follows: "Many Europeans today think they know what Christianity is, yet they do not really know it at all. Often they lack knowledge of the most basic elements and notions of the faith. Many of the baptized live as if Christ did not exist: the gestures and signs of faith are repeated, especially in devotional practices, but they fail to correspond to a real acceptance of the content of the faith and fidelity to the person of Jesus." ${ }^{46}$

42 According to John Paul II, "Jesus is the truth of the universe and history, the meaning and destiny of human life, the foundation of all reality. You who have accepted this truth as a vocation and certainty of your life should show the legitimacy of this choice in your environment and your university work. We must therefore ask ourselves: what influence does the truth of Christ have on your studies, research, cognition of reality, and on the integral formation of the person? It happens that some, including those who say they are Christians, act as if God did not exist at the university. Christianity is not simply a subjective choice of a religious option, essentially irrational and private. As Christians, we have a duty to bear witness to what the Second Vatican Council affirms in its Constitution Gaudium et Spes: "Faith illuminates everything with new light, reveals the divine intention for the whole vocation of man and therefore directs the mind towards fully human solutions (no. 11)" (Jan Paweł II, "Przesłanie Jana Pawła II," 3).

43 Jan Paweł II, Ecclesia in Europa, no. 47.

44 Jan Paweł II, Ecclesia in Europa, no. 47.

45 Wyszyński, "Kamienie węgielne budowania na górach świętych," 64.

46 Jan Paweł II, Ecclesia in Europa, no. 47. 
The striving for personal fullness, rooted in human nature, is realized primarily in the orientation towards truth, goodness, and beauty, leading to holiness. Reflection and thinking become the necessary initiators of culture-forming activities and determine their shapes. Between the rational nature of man and culture, there is a mutual complementarity relationship. Thanks to his mind, the human person does not get lost in the matter but masters it. He can use natural phenomena to fulfill his intentions purposefully, discover relationships between particular facts, and formulates general judgments. ${ }^{47}$

In this sense, even a cursory familiarization with the effects of secularization and religious indifferentism becomes a challenge to reach out to people who share the views and attitudes in life. Undoubtedly, new forms of atheization that defile religiously motivated morality are becoming a severe challenge for the Church of the 21 st century. Thus, an essential dimension of involvement in culture is the humanization of the entire reality of human life, which is at the same time the area of cultural activity and cultural impact. If the human person is the goal and sense of culture, then man's values become its fundamental framework. These are, above all, the traditional values of truth, goodness, beauty, and holiness. Their essential role is that they constitute the basis of the culture of the spirit, and hence of all Western civilization. ${ }^{48}$

At the same time, cognitive, moral, artistic, and ideological values are not only means of achieving other goals and intentions, but they are the fundamental core of human culture: they are permanent in time and always valid. Moreover, for every human being, they set the direction of life - thus, they constitute essential criteria for assessing the behavior of all people. The implementation of these axiologically fundamental values determines the personal maturation of a human being. It is also a manifestation of the human person's potentialized nature, which strives for comprehensive development. Thanks to this, man becomes an authentic creator of culture. In a spiritual sense, Christian maturity opens in front of him the fullness of the truth inherent in the earthly reality that he is to transform.

Unfortunately, contemporary democratic structures and mechanisms exclude the centrality of religion in public and cultural life and, consequently, a significant influence of the Church in society. Nevertheless, John Paul II interprets this as the most urgent task of the contemporary Church, especially in the "Old Continent." Therefore, the Pope calls: "In the church in Europe, the 'new evangelization' is the task set before you! Rediscover the enthusiasm of proclamation. Hear today, addressed to you at the beginning of this third millennium, the plea heard at the beginning of the first millennium. [...] Even if it remains unexpressed or even repressed, this is the most profound and genuine plea rising from the hearts of Europeans today, who

\footnotetext{
47 Cf. Celej, Kultura chrześcijańska duszą narodu, 109.

48 Cf. Wyszyński. "Ale nie depczcie przeszłości ołtarzy...," 378-382.
} 
yearn for a hope which does not disappoint. This hope has been bestowed on you as a gift, which must then be joyfully given away in every time and place. Let the proclamation of Jesus, which is the Gospel of hope, be your boast and your whole life." ${ }^{\prime 9}$

\section{Towards Redeeming the Culture}

In common understanding, contemporary postmodernism tries to situate Christian culture on the "unreal" margin of everyday life, just as superficial treatment of faith closes it in the private sphere of human spiritual experiences (religious indifferentism) and does not link it with the shape of everyday life and the ways of thinking and acting that create it. Making life choices, making decisions, courses of functioning among people, experiencing joy and drama, doing work, and celebrating. In the perspective of contemporary postmodern concepts, faith and culture try to deprive themselves of their true meaning. ${ }^{50}$ In this light, it is not surprising that (post) modern culture - as a form of life in modern societies - only to a small extent expresses the faith of individuals and communities in God and transcendental values. The Christian culture itself is interpreted instead as an artistic creation that reaches more to Christian themes than arises from the foundations of Christian faith - that is, a culture that expresses and confirms its creator's faith. And the creators of culture are not only the creators of works of spiritual culture, art, and science but all those who - through culture - build their lives, giving it a shape more or less consistent with their own faith. ${ }^{51}$

49 Jan Paweł II, Ecclesia in Europa, no. 45.

50 As Pope John Paul II repeatedly emphasized that the teaching of the Council, related to the relationship between faith and culture, penetrates with such difficulty into the practice of the Church's life and the contemporary Christians' attitudes. The words from the beginning of the pontificate (from 1982) to the representatives of the community of one of the European universities are significant: "There is no contradiction between culture and faith, as clearly emphasized by the Second Vatican Council; on the contrary, they can explain and enrich each other. Hence the special responsibility of Christian scientists and Catholic universities, the responsibility to contribute to the removal of a serious imbalance between general culture and the deepening of faith, which - as it seems - often ends prematurely, which must have an impact on the conduct of Christians and their presence in the world" (Jan Paweł II, "Dobro kulturalne każdego człowieka," 146).

51 The relationship between faith and culture has been a profound concern of the Church, especially since the Second Vatican Council. One of the most important documents of this Council, completed in December 1965, is the "Pastoral Constitution on the Church in the Modern World Gaudium et Spes." It should be noted that Karol Wojtyła was one of the most active participants in the work on this document. In the context of the considerations presented here, particular attention should be paid to the chapter of this Constitution devoted to developing culture (and thus the relationship of the Church with contemporary culture) and the tasks of Christians in the development of culture. At this point, it seems necessary to quote the definition of culture adopted in the same Constitution, according to which: "culture in a general sense denotes everything that man perfects and develops the multiple talents of his spirit and body; tries, 
The problem of translating faith into the culture will later become one of the most important themes of the pontificate of John Paul II, as well as the teaching of Cardinal Wyszyński. Why is it so important today to prevent faith and culture from drifting apart both in people's consciousness and in their lives? In this sense, it is vital to have a Christian concept of culture based on human improvement's personal and community dimensions. In other words, as an expression and confirmation of man, Christian culture is deeply rooted in the Gospel. It draws its dynamism from it, the truth about man, the meaning and purpose of his life, and the love of God that accompanies him..$^{52}$ Man creates himself through the inner effort of the spirit: thoughts, will, heart. At the same time, however, man creates a culture in community with others. Culture is an expression of interpersonal communication, co-thinking, and human cooperation. It is generated at the service of the common good - and becomes the fundamental good of human communities. ${ }^{53}$

In personalist terms, culture is thus understood as all creative activity of a human being. Through culture, man rationally and purposefully develops himself and the world, creating values that are revealed and lasted in the form of internalized works of culture, social structures, value systems, and technological achievements. Thus, the essential cultural factors have a double character: (1) impersonal because they come from the material world; (2) and personal, they are rooted in the human person or are directly related to him. Although they are of two kinds: personal and impersonal, spiritual and material, more active and rather the material basis for creating culture, they are always necessary, never separate and singular, but interpenetrate and complement each other to form a common human culture. ${ }^{54}$

Moreover, culture is a reality shaped by man in specific historical conditions. It cannot be created in isolation from the material world. It is very closely related to the human person from the act of creation and is the basis of his existence and action - the basis for the creation of human culture and history. Therefore, non-personal factors - coming from the world of matter - play a significant role. ${ }^{55}$ Due to material elements, human spirituality can express itself. In this sense, the matter becomes the substance for interiorizing all spiritual endowments. Components of inanimate matter become, at the same time, essential building blocks, substance, and "language" that man needs to implement their inner ideas. They are also an indispensable ele-

through knowledge and work, to bring the world itself under its control; makes social life more human, both in the family and in the entire state community, through the progress of morals and the efforts of institutions; finally, in his works over the centuries, he expresses, transmits and maintains great spiritual experiences so that they may serve the progress of many, and even the whole of humanity (Gaudium et spes, no. 53).

Cf. Jan Paweł II, “Fragment przemówienie w czasie Katholigentagu," 10-14.

53 Cf. Jan Paweł II, "Przemówienie do młodzieży na Wzgórzu Lecha," 723.

54 Cf. Celej, Kultura chrześcijańska dusza narodu, 63-77.

55 Cf. Ficek, "(Post-) Modernity and Christian Culture," 50-54. 
ment of preserving and storing all the achievements of man's intellectual and aesthetic culture. Thus, a vital factor in the creation and existence of any artistic work. ${ }^{56}$

The human being's complex structure is expressed primarily in the multidimensional activity for transforming the temporal world, which creates the reality of technical, civilization, scientific, biological, social, and cultural progress. This dynamic of progress and comprehensive development, including cultural development, includes the missionary command of Jesus Christ: "Go into the whole world and make disciples of all peoples by baptizing them" (Matt 28:19). The missionary mandate defines the fundamental mission of the Church, which is evangelization, which is "[...] proclaiming the Good News of Jesus Christ in the modern world." ${ }^{57}$ Above all, understanding and putting into practice Christ's teaching was not an easy task for early Christians as they had no ready-made model of culture to follow

Nevertheless, "by becoming man, the Son of God brought into the history of mankind all the Gospel riches of truth and goodness, and with it also revealed a new dimension of beauty: the Gospel message is filled to the brim with it." ${ }^{58}$ In this sense, "cultural good" - that is, the inner culture of one person - is a value for others: "the greater one's" cultural "is, the more it must be used - consciously, actively, responsibly and in a Christian way - as a 'value for others." 59 This thought opens up critical perspectives for analyzing the educational consequences of the relationship between faith and culture. If faith is a gift from God, the daily devoted practice of faith in every area of life creates a truly human culture. Thus, God's gift to a person who builds his life on faith becomes, precisely through culture, God's gift to others. ${ }^{60}$

Therefore, a unique and irreplaceable role in culture understood as seeking and discovering the truth about man and the world is played by science and art together with their separate ways of knowing. In this context, it is crucial to bring the scientific and creative circles closer to the Church, making them aware of their mission in the world and the importance of constant dialogue with faith, the value of this dialogue for both spheres of human life - culture (in this case science and art) and faith. In the texts of both John Paul II and Cardinal Wyszyński, the appeal for defending the truth, appreciating and giving justice to all ways of knowing the truth, in all their

\footnotetext{
56 Cf. Celej, Kultura chrześcijańska duszą narodu, 76-77.

57 Wyszyński, "Ewangelizacja świata," 4.

58 Jan Paweł II, List do artystów, 5.

59 Jan Paweł II, “Dobro kulturalne każdego człowieka," 148.

60 "The creator of culture, the Cardinal emphasizes in his teaching, is first and foremost a human person. Although communities such as the state or nation may create more favorable conditions for its development, the ultimate creator, maker, and inspiration is the man himself" (Wyszyński, "Konstytucja Pastoralna,"119-120). In this context, personalism emphasizes two essential aspects of human involvement in culture. On the one hand, the man gives shape to the culture in which he reflects his interior. On the other hand, through culture, he develops and shapes this interior. The integral connection of these two elements of culture means that although they constitute a whole, they interpenetrate, co-create and condition each other. Cf. Celej, Kultura chrześcijańska dusza narodu, 31.
} 
autonomy and specificity - both through faith and through scientific cognition, and finally - contact with beauty. ${ }^{61}$ The most important thing is that all those who choose a given path should be accompanied by the awareness of one truth that everyone strives for, openness to mutual inspirations that may result from their dialogue, responsibility for the actions taken, and their ethical dimension. ${ }^{62}$

In other words, science is seen through the prism of a personalist vision of culture. If it is to support man and the world's development, must accept the "human dimension of culture. ${ }^{63}$ In this sense, the culture - as a fruit of faith, as well as art - does not have to be limited to explicit religious references. It's rooting in faith is determined by it's honesty in striving for the truth, it's attitude towards man and the world seen more broadly than in the context of material existence and pragmatic survival. ${ }^{64}$ The sphere of values in the personalist approach is understood not only as Christianity's reality but also as a deposit cultivated in social life.

The axiological dimension of involvement in culture is realized primarily in the concern for the penetration of the entire reality of social life - human culture - with Christian values that lead to discovering the whole truth about the human person. ${ }^{65}$

Contact with art is not only a way of discovering the truth about the man but also of uncovering God. Culture is the road to faith here because it grows out of it. In this sense, the significant and eminent path to God is through beauty, which is an extraordinary dimension of the world created by God. Therefore, an essential element of the Church's life is caring for them, especially caring for the beauty of the liturgy. The highest achievements of the human spirit - high culture embracing the most outstanding works and activities, exceptional in discovering the truth about the world and people, about their experience and living life - awaken in man the need for truth, longing for beauty, readiness to do good, and sensitivity to transcendence. Thus, they open to the grace of faith. The history of culture displays that many of these great works grew out of a profound experience of faith. They represent a kind of testimony to the richness of people seeking God and finding Him. Thus,

61 Cf. John Paul II, Fides et Ratio, no. 12.

62 Cf. Cichocki, "Etos wychowawcy," 323-344.

63 In one of his speeches to people of science, John Paul II said: "As scholars and researchers, you are an international community whose activity can be decisive for the future of humanity, but on the condition that you are able to serve the true culture of man and protect this precious heritage. Your noble task is to work on the development of man, not only his possessions, knowledge, or strength. [...] This concept of culture results from the holistic view of man as a unity of body and soul, person and community, a rational being and ennobled by love" (Jan Paweł II, "Przemówienie na Uniwersytecie," 310).

64 As John Paul II put it: "For art, if it is authentic, although it does not necessarily express itself in typically religious forms, maintains the bond of internal kinship with the world of faith, so that even in the situation of a deep split between culture and the Church, art remains a kind of bridge leading to a religious experience. As a search for truth, the fruit of imagination that goes beyond everyday life, art is by nature a specific call to open up to the Mystery" (Jan Paweł II, List do artystów, no. 10). 
the world of works of artistic culture, transmitting the experiences of individual people, societies, or nations, is an essential building block and binder of their memory and identity, help in understanding themselves and their community, a factor that strengthens or weakens the sense of trying to improve oneself and one's world. ${ }^{66}$

Another important culture-creating environment is the school, understood as a place of formal education, as well as an educational and upbringing institution. But school is also an environment in which the young generation spends a large part of their lives, which is extremely important to their development. The school, therefore, plays a particular role in shaping man and thus in shaping culture. The cultural dimension of human education is a reality directly related to many spheres of human life: it is the totality of behaviors based on native and universal models, drawn from history and the Bible, provided by the home, school, church, and encoded in literature, theater, and art. Culture is wherever a person undertakes the full development of his spiritual life, both in the cognitive sphere and in the field of conduct and production. Culture is where a man gives his life a more prosperous and deeper shape, where it imprints its spirituality on life and works, on relations with God, with people, and with nature.

Each school is part of society and a nation's broader culture, introducing and building culture while constructively and creatively participating in it. At the same time, as a community, it has its own internal culture - its history, tradition, rituals, symbolism, its values, patterns, norms both formally declared and written and informally functioning, typical behavior of members of the school community, language and methods of communication, ways of solving problems, style of action and atmosphere. Finally, school is one of the primary environments that should support the family in education. ${ }^{67}$

In the light of the Christian concept of culture, upbringing means a process situated in the very center of culture as a space for the improvement of humanity. From this perspective, each school, being an institution that educates, enlightens, stimulates, and supports students' development, should, at least, try to counteract the emergence of a "torn" culture, the development of a culture of individual and group egoism. On the contrary, it should, by all means, work for a "genuinely personalist" culture.

The apparent direction of looking for answers is associated with strengthening the school's educational function, assuming constant care for the education level. ${ }^{68}$

\footnotetext{
66 Cf. Jan Pawet II, Wstańcie, chodźmy!, 74-75.

67 Cf. Cichocki, "Etos wychowawcy," 345-346.

68 In many documents of the Church, as well as in the teachings of popes and their statements to various bodies, the problem of the dominance of education by narrowly understood education, which is dangerous for today's culture, returns many times. Unfortunately, the diagnosis of John Paul II expressed as early as 1979 in words: "I think that more and more in the modern world, in different world systems, created on the basis of different ideologies, which, moreover, have quite a common root, more and more it will
} 
Education that constitutes and creates an authentic, personalist culture must equip young people with competencies that are not limited to instruments of effective acquisition and "possession" of knowledge and skills valuable on the labor market and everyday institutional and social functioning. To develop humanity, we need broader competencies that allow us to prepare ourselves more "to be." In practice, it means a better understanding of the world, making choices in it by recognized values and moral standards, making an effort to learn the truth, contemplate beauty, achieve good by becoming "good" for others and building the common good, and on this path, creating goodness in himself. ${ }^{69}$

It also includes activities aimed at preparing a young person to enter the culture so that he can understand his own culture, find his place in it, appreciate the role of cultural identity in his life, the lives of his relatives, his community and nation, and consequently actively defend its most important values. Preparing people to be able and willing to work more and more consciously to "be," to work on oneself, on their humanity, is the essence of the personalist vision of upbringing. It is the process of leading and then supporting and accompanying the path to values, character education, building positive attitudes and attitudes characteristic of a Christian. ${ }^{70}$

Shaping a culture that is to be the genuine fruit of faith must begin with deepening the personal relationship with God. An essential step in this direction should be a deep understanding, acceptance, and implementation by Christians the message: what does it mean to be a Christian? Seeing the fruit of faith in culture, as well as the conscious building of culture in oneself and the world based on faith, requires reliable, persistent educational and formative work that would increase the awareness of the essence of this process in individuals and societies, i.e., realizing and fulfilling the truth about man and the world in the Christian spirit in love. ${ }^{71}$

\section{Conclusions}

The personalist perspective of Christian culture, strongly emphasized both in the teachings of John Paul II and Primate Wyszyński, displays the human person primarily as its only direct source and goal. A man understood as a unique and mysterious being,

be obvious that the production of educated, highly trained, specialized units alone does not solve [...] the problem of man" (Jan Paweł II, "Przemówienie do profesorów," 731). 
but at the same time close to the world, is called to realize his person and achieve his ultimate goal by shaping his own existence and changing the reality of the world.

Thus, by creating a world culture, man forms his own personalist culture, shapes and completes his personality, thus becoming a person in an ontological and moral sense. In this context, culture understood personalistically becomes the only way to create full humanity, both in the temporal and eschatological dimensions. In other words, in personalist cultural anthropology, a man appears as an eternally intended being - rooted in God's mind and embodied in a concrete historical reality. Its total value, however, is expressed in the perspective of two fundamental salvation events: the creation of man in the image and likeness of God and the salvific event of Jesus Christ.

Thus, the perspective of the extraordinary value and dignity of the human person becomes an essential feature of the personalist vision of involvement in culture. In this sense, the man directly touches God with his person, elevating him above all other creatures. The nature of the human person distinguishes him from other beings not only in a purely descriptive but also axiological sense. For this reason, man is more valuable than other beings on earth. This value, resulting from being a person and referred to as personal dignity, imposes both on man and society. He should respect it, which means to live "according to the measure of the human person."

For a Christian who treats activity in the field of culture as an element of his vocation, God is the final and deepest reference point and responsibility. Therefore, Christian culture-forming activity presents man with the prospect of cooperation with God. For there is no such form of external endeavor that could not be included in the sphere of spiritual work - that is, into such a dynamic contact with God that, by creating optimal conditions for human cultural development, is at the same time directed to God as the final goal. As it came out of God's hand, the world is a perfect work of creation, but it is not a finite, unchanging perfection. The world is not made so that a man would be only a passive user of it, like the resident of an enchanted castle. On the contrary, although the world is intended for man, he can continually add something more to God's harmony.

Therefore, culture - understood in personalist terms, both individual and social - ultimately improves the human person by learning the truth, doing good, and creating beauty in love. Due to the social nature of personalist Christian culture, all its essential elements have a supra-individual dimension. They enable the development of all social structures, as well as conditioning their identity, uniqueness, and sovereignty. 


\section{Bibliography}

Bartnik, C.S., “Osoba i Kościół wg Kardynała K. Wojtyły,” Colloquium Salutis 15 (1983) 83-101. Bartnik, C.S., Teologia kultury (Lublin: Standruk 1999).

Catto, R., "Interfaith Dialogue and the Challenge of Indifference: Reflections from Fieldwork in the City of Peace and Reconciliation," Religious Indifference. New Perspectives from Studies on Secularization and Nonreligion (eds. J. Quack - C. Schuh) (Cham: Springer International Publishing 2017) 65-82.

Celej, J.Z, Kultura chrześcijańska duszą narodu (Warszawa: Wydawnictwo Sióstr Loretanek 1995).

Cichocki, A., "Etos wychowawcy w nauczaniu Jana Pawła II," Ideały wychowania i wzory osobowe narodu polskiego w XIX i XX wieku (ed. E.J. Kryńska) (Białystok: Trans Humana Wydawnictwo Uniwersyteckie 2006) II, 342-352.

Ficek, R., "(Post-) Modernity and Christian Culture: in the Context of the Personalism of Stefan Cardinal Wyszyński," Roczniki Kulturoznawcze 11/2 (2020) 49-89.

Jan Paweł II, Adhortacja Apostolska "Ecclesia in Europa," https://opoka.org.pl/biblioteka/W/ WP/jan_pawel_ii/adhortacje/europa_28062003.html [access: 29.12.2020].

Jan Paweł II, Czwarta Pielgrzymka do Polski (Poznań - Warszawa: Pallottinum 1991).

Jan Paweł II, "Dobro kulturalne każdego człowieka jest wartością dla innych. Przemówienie do przedstawicieli Katolickiego Uniwersytetu Portugalskiego, Lizbona, 14.05.1982," Jan Paweł II, Wiara i kultura. Dokumenty, przemówienia, homilie (Rzym: Polski Instytut Kultury Chrześcijańskiej. Fundacja Jana Pawła II 1986) 142-151.

Jan Paweł II, Evangelii nuntiandi, https://www.vatican.va/content/paul-vi/en/apost_exhortations/documents/hf_p-vi_exh_19751208_evangelii-nuntiandi.html [access: 29.12.2020].

Jan Paweł II, Evangelium vitae, http://www.vatican.va/content/john-paul-ii/pl/encyclicals/ documents/hf_jp-ii_enc_25031995_evangelium-vitae.html [access: 29.12.2020].

Jan Paweł II, Familiaris consortio, http://www.vatican.va/content/john-paul-ii/pl/apost_exhortations/documents/hf_jp-ii_exh_19811122_familiaris-consortio.html [access: 29.12.2020].

Jan Paweł II, "Fragment przemówienie w czasie Katholigentagu w Austrii, Wiedeń, 10.09.1983," Europa droga Kościoła. Jan Paweł II o Europie i europejskości (eds. S. Sowiński - R. Zenderowski) (Wrocław: Zakład Narodowy imienia Ossolińskich 2003) 10-14.

Jan Paweł II, Laborem exercens, http://www.vatican.va/content/john-paul-ii/pl/encyclicals/ documents/hf_jp-ii_enc_14091981_laborem-exercens.html [access: 29.12.2020].

Jan Paweł II, List do artystów, https://opoka.org.pl/biblioteka/W/WP/jan_pawel_ii/listy/ do_artystow_04041999.html [access: Jan 2, 2021].

Jan Paweł II, List do rodzin “Gratissimam sane," https://opoka.org.pl/biblioteka/W/WP/jan_ pawel_ii/listy/gratissimam.html [access: 29.12.2020].

Jan Paweł II, Posynodalna adhortacja apostolska "Christifideles laici," http://www.vatican. va/content/john-paul-ii/pl/apost_exhortations/documents/hf_jp-ii_exh_30121988_ christifideles-laici.html [access: 29.12.2020].

Jan Paweł II, "Powołanie do życia Papieskiej Rady do spraw Kultury (List do kardynała Sekretarza Stanu, 20 V 1982)," Jan Paweł II, Nauczanie papieskie. V/1. 1982 (Poznań: Pallottinum 1993) 765-768. 


\section{CHRISTIAN FAITH IN DIALOGUE WITH CONTEMPORARY CULTURE}

Jan Paweł II, “Przemówienie do ludzi nauki i kultury, Praga, 21.04.1990," Przemówienia i homilie Ojca Świętego Jana Pawła II (Kraków: Znak 2008) 331-342.

Jan Paweł II, “Przemówienie do młodzieży na Wzgórzu Lecha w Gnieźnie, 3.06.1979," https:// ekai.pl/dokumenty/przemowienie-do-mlodziezy-zgromadzonej-na-wzgorzu-lecha/ [access: 29.12.2020].

Jan Paweł II, "Przemówienie do profesorów i studentów Katolickiego Uniwersytetu Lubelskiego, 6.06.1979," http://nauczaniejp2.pl/dokumenty/wyswietl/id/625/pos/2/haslo/indywidualizm [access: 29.12.2020].

Jan Paweł II, "Przemówienie na Uniwersytecie Narodów Zjednoczonych w Hiroszimie, 25.02.1981," Przemówienia i homilie Ojca Świętego Jana Pawła II (Kraków: Znak 2008) 308-313.

Jan Paweł II, "Przesłanie Jana Pawła II do uczestników VIII Międzynarodowego Forum młodzieży, Watykan, 25 marca 2004,” http://www.nauczaniejp2.pl/dokumenty/wyswietl/ $\mathrm{id} / 1379$ [access: 29.12.2020].

Jan Paweł II, Redemptor hominis, http://www.vatican.va/content/john-paul-ii/pl/encyclicals/ documents/hf_jp-ii_enc_04031979_redemptor-hominis.html [access: 27.12.2020].

Jan Paweł II, Veritatis splendor, http://www.vatican.va/content/john-paul-ii/pl/encyclicals/ documents/hf_jp-ii_enc_06081993_veritatis-splendor.html [access: 26.12.2020].

Jan Paweł II, "W imię przyszłości kultury," Poznać człowieka w Chrystusie. Jan Paweł II o godności ludzkiej (eds. J. Kowalski - D. Sikorski - G. Ślęzak) (Częstochowa: Częstochowskie Wydawnictwo Diecezjalne 1983) 197-198.

Jan Pawet II, Pamięć i tożsamość (Kraków: Znak 2005).

Jan Paweł II, Wstańcie, chodźmy! (Kraków: Wydawnictwo św. Stanisława BM Archidiecezji Krakowskiej 2004).

John Paul II, Apostolic letter “Tertio Millennio Adveniente," http://www.vatican.va/content/ john-paul-ii/en/apost_letters/1994/documents/hf_jp-ii_apl_19941110_tertio-millennio-adveniente.html [access: 26.12.2020].

John Paul II, Encyclical Letter 'Fides et Ratio', http://www.vatican.va/content/john-paul-ii/en/ encyclicals/documents/hf_jp-ii_enc_14091998_fides-et-ratio.html [access: 2.01.2021].

John Paul II, Inde a Pontificatus, The Pontifical Council for Culture and the Pontifical Council for Dialogue with Non-Believers Are United, https://www.vatican.va/content/john-paul-ii/en/ motu_proprio/documents/hf_jp-ii_motu-proprio_25031993_inde-a-pontificatus.html [access: 29.12.2020].

Kerber, W., "Führungsethik in einer säkularisierten Industriegesellschaft," Stimmen der Zeit 205/10 (1987) 651-661.

Kowalczyk, S., Człowiek a społeczność. Zarys filozofii społecznej (Lublin: RW KUL 1996).

Kowalczyk, S., Filozofia kultury. Próbapersonalistycznego ujęcia problematyki (Lublin: RW KUL 1997).

Legutko, R., "O tolerancji, ” Religia a sens bycia człowiekiem (ed. Z.J. Zdybicka) (Lublin: RW KUL 1994) 113-132.

Lübbe, H., Der Lebenssinn der Industriegesellschaft. Über die moralische Verfassung der wissenschaftlich-technischen Zivilisation (Berlin - New York: Springer 1993).

Mariański, J., Religia i Kościół w społeczeństwie pluralistycznym (Lublin: RW KUL 1993). 


\section{RYSZARD FICEK}

Mariański, J., Młodzież między tradycja i ponowoczesnością. Wartości moralne w świadomości maturzystów (Lublin: RW KUL 1995).

Nash, D., "Genealogies of Indifference? New Theoretical Thoughts on the History and Creation of Narratives Surrounding Christianity, Secularism and Indifference," Religious Indifference. New Perspectives from Studies on Secularization and Nonreligion (eds. J. Quack C. Schuh) (Cham: Springer International Publishing 2017) 25-42.

Pottmeyer, J., “Die Zeichen der Zeit - Grund zur Zuversicht?, Pastoralblatt 45 (1993) 166-176. Poupard, P., "Non-croyance et cultures d'aujourd'hui," Nouvelle Revue Théologique 115 (1983) 3-21.

Sobór Watykański II, "Konstytucja duszpasterska o Kościele w świecie współczesnym Gaudium et spes," Sobór Watykański II, Konstytucje, dekrety, deklaracje (Poznań: Pallottinum 1967) 537-619.

Swastek, J., "Laicyzacja życia publicznego jako program oświaty i kultury w PRL," Chrześcijanin $w$ Świecie 26/1 (1994) 23-32.

Wojtyła, K., Miłość i odpowiedzialność (Lublin: TN KUL 2019).

Wojtyła, K., Osoba i czyn oraz inne studia antropologiczne (ed. T. Styczeń) (Lublin: TN KUL 1994).

Wojtyła, K., Osoba i czyn (Kraków: Polskie Towarzystwo Teologiczne 1969).

Wojtyła, K., "Podmiotowość i «to co nie redukowalne» w człowieku," "Osoba i czyn” oraz inne studia antropologiczne (eds. T. Styczeń et al.) (Lublin: TN KUL 1994) 433-443.

Wyszyński, S., “"Ale nie depczcie przeszłości ołtarzy...». Podczas poświęcenia ołtarza w kościele Świętego Krzyża w Warszawie 19.01.1969,” S. Wyszyński, Nauczanie społeczne. 1946-1981 (Warszawa: ODISS 1990) 378-382.

Wyszyński, S., “"Homo Dei.» I kazanie świętokrzyskie 13.01.1974,” S. Wyszyński, Nauczanie społeczne. 1946-1981 (Warszawa: ODISS 1990) 574-580.

Wyszyński, S., “Jasnogórskie zobowiązania... Bydgoszcz 19.12.1956," Kazania i przemówienia autoryzowane 1956-1981 (Archiwum Instytutu Prymasowskiego w Warszawie) I, 303-304.

Wyszyński, S., "Chrystusa nie można wyłączyć z dziejów człowieka. 23.11.1980," S. Wyszyński, Kościół w służbie Narodu (Poznań: Pallotinum 1981) 297-302.

Wyszyński, S., “Do uczestniczek zjazdu pielęgniarek. Warszawa-Wawer 30.12.1956," Kazania i przemówienia autoryzowane 1956-1981 (Archiwum Instytutu Prymasowskiego w Warszawie) I, 334-341.

Wyszyński, S., "Ewangelizacja świata w ocenie Synodu Biskupów w Rzymie. Warszawa - kościół św. Krzyża. 12.01.1975,” S. Wyszyński, Kazania świętokrzyskie (Rzym: Rycerz Niepokalanej 1975) 4-17.

Wyszyński, S., "Jesteśmy z miłości i dla miłości," S. Wyszyński, Miłość na co dzień. Rozważania (Poznań: Księgarnia Świętego Wojciecha 1980) 8-15.

Wyszyński, S., "Kamienie węgielne budowania na górach świętych. Na Jasnej Górze po powrocie z uwięzienia 2.11.1956," S. Wyszyński, Nauczanie społeczne. 1946-1981 (Warszawa: ODISS 1990) 62-67.

Wyszyński, S., "Konstytucja Pastoralna o obecności Kościoła w świecie współczesnym, Warszawa - bazylika św. Jana 20.03.1966," Kazania i przemówienia autoryzowane 1956-1981 (Archiwum Instytutu Prymasowskiego w Warszawie) XXIII, 103-124. 


\section{CHRISTIAN FAITH IN DIALOGUE WITH CONTEMPORARY CULTURE}

Wyszyński, S., “Kościół wspólnototwórczy. Warszawa-Miodowa 4.08.1970," Kazania i przemówienia autoryzowane 1956-1981 (Archiwum Instytutu Prymasowskiego w Warszawie) XXXIV, 145-156.

Wyszyński, S., “Krzyż na szlaku Warszawy. Warszawa - kościół świętego Aleksandra 8.09.1973,” Kazania i przemówienia autoryzowane 1956-1981 (Archiwum Instytutu Prymasowskiego w Warszawie) XXXVI, 16-20.

Wyszyński, S., "Kształtowanie kultury społeczno-katolickiej w Polsce. Do prawników 15.01.1971,” S. Wyszyński, Nauczanie społeczne. 1946-1981 (Warszawa: ODISS 1990) 436-444.

Wyszyński, S., "List pasterski O chrześcijańskim wyzwoleniu człowieka," Listy pasterskie Episkopatu Polski 1946-1974 (Paryż: Éditions du Dialogue 1975) 30-46.

Wyszyński, S., "Najważniejszą wartością na świecie jest człowiek. Warszawa 19.10.1980," S. Wyszyński, Nauczanie społeczne. 1946-1981 (Warszawa: ODISS 1990) 960-965.

Wyszyński, S., "Nie oczekujemy życia łatwego. Podczas ingresu do katedrylubelskiej 26.05.1946," S. Wyszyński, Nauczanie społeczne. 1946-1981 (Warszawa: ODISS 1990) 9-13.

Wyszyński, S., "O chrześcijańskim wyzwoleniu człowieka. List pasterski na adwent 1946," S. Wyszyński, Nauczanie społeczne. 1946-1981 (Warszawa: ODISS 1990) 14-28.

Wyszyński, S., “O katolickiej woli życia. List pasterski na Wielkanoc 1947,” S. Wyszyński, Nauczanie społeczne. 1946-1981 (Warszawa: ODISS 1990) 29-40.

Wyszyński, S., “O nowym człowieku w Jezusie Chrystusie. Jasna Góra 3.05.1964,” Listy pasterskie Episkopatu Polski 1945-1974 (Paris: Éditions du Dialogue 1975) 348-356.

Wyszyński, S., “Ojcze nasz, Warszawa 4-8.12.1961," Kazania i przemówienia autoryzowane 1956-1981 (Archiwum Instytutu Prymasowskiego w Warszawie) XIX, 312-436.

Wyszyński, S., “«Ojczyznę wolną zachowaj nam Panie!». Z okazji 50 rocznicy odzyskania niepodległości. Jasna Góra 15.09.1968,” S. Wyszyński, Nauczanie społeczne. 1946-1981 (Warszawa: ODISS 1990) 367-369.

Wyszyński, S., "Społeczność przyrodzona i nadprzyrodzona. II Konferencja Akademicka. Warszawa - kościół św. Anny 16. 02. 1957," Kazania i przemówienia autoryzowane 1956-1981 (Archiwum Instytutu Prymasowskiego w Warszawie) II, 57-79.

Wyszyński, S., “Tajemnica więzi z ojczyzną, Do młodzieży polskiej z Londynu 7.01.1972,” S. Wyszyński, Nauczanie społeczne. 1946-1981 (Warszawa: ODISS 1990) 483-487.

Wyszyński, S., Uświęcenie pracy zawodowej (Paris: Éditions du Dialogue 1963).

Wyszyński, S., "W słodkim jarzmie miłości. Warszawa 1.06.1967," Kazania i przemówienia autoryzowane 1956-1981 (Archiwum Instytutu Prymasowskiego w Warszawie) XXVI, 378-399.

Wyszyński, S., "Zadania i środki oddziaływania Kościoła w Polsce w zakresie kształtowania kultury społeczno-katolickiej, Warszawa - kościół św. Anny 15.01.1971," Kazania i przemówienia autoryzowane 1956-1981 (Archiwum Instytutu Prymasowskiego w Warszawie) XXXVI, 56-71.

Wyszyński, S., “Zaszczytna służba Słowu. Warszawa - Miodowa 8. 10. 1976,” S. Wyszyński, Z rozważań nad kulturą ojczysta (Warszawa: PAX 1998) 266-271. 
